\title{
Impact of maternal age on caesarean delivery rate under epidural labor analgesia
}

Arimoto S, Wakimoto M, Taniguchi A, Kinouhi K

Osaka Medical Center and Research institute for Maternal and Child Health,

Dept of Anesthesiology, Osaka, Japan

\section{Background and Goal of study}

It has been proposed that epidural analgesia is not related to the increase of caesarean delivery rate. However, some previous studies have shown that advanced maternal age was the independent risk factor for caesarean delivery.

The aim of this study is to determine whether the maternal age is associated with an increased risk of emergency caesarean delivery rate under epidural labor analgesia.

\begin{tabular}{|c|c|c|c|c|c|}
\hline \multicolumn{6}{|c|}{ Methods } \\
\hline Study desi & & \multicolumn{4}{|c|}{ Retrospective study } \\
\hline \multicolumn{2}{|c|}{$\begin{array}{l}\text { Eligibility } \\
\text { criteria }\end{array}$} & \multicolumn{4}{|c|}{$\begin{array}{l}\text { Inclusion } \\
\text { - Women aged from } 20 \text { to } 49 \\
\text { - Received epidural labor analgesia } \\
\text { - Delivered between } 36 \text { and } 42 \text { week's gestation, } \\
\text { vaginally or by emergency caesarean section } \\
\text { Exclusion } \\
\text { - Women who had contraindications to labor } \\
\text { - Deliveries for abortion or fetal death }\end{array}$} \\
\hline \multicolumn{2}{|c|}{$\begin{array}{l}\text { Statistical } \\
\text { analysis }\end{array}$} & \multicolumn{4}{|c|}{$\begin{array}{l}\text { - Divided subjects into } 3 \text { age groups }(<35,35-39 \text {, } \\
40<\text { years) } \\
\text { - A bivariate analysis of each group and } \\
\text { emergency cesarean rate was conducted with } \\
\text { Chi-square test } \\
\text { - Used multivariate logistic regression analysis } \\
\text { to assess the effect of age on outcomes } \\
\text { adjusting for induction status, parity, and birth } \\
\text { weight }\end{array}$} \\
\hline \multicolumn{6}{|c|}{$\begin{array}{l}\text { Results } 1 \\
\text { Table1 Patient characteristics by maternal age }\end{array}$} \\
\hline & & $\begin{array}{c}<35 \text { years } \\
N=116\end{array}$ & $\begin{array}{c}\text { 35-39 years } \\
N=74\end{array}$ & $\begin{array}{c}40<\text { years } \\
N=36\end{array}$ & $p$ value \\
\hline \multicolumn{2}{|l|}{ Mean age } & 29.8 & 36.7 & 41.4 & $<0.01^{*}$ \\
\hline \multicolumn{2}{|c|}{ Mean BMI $\left(\mathrm{kg} / \mathrm{m}^{2}\right)$} & 25.8 & 25.9 & 25.8 & 0.99 \\
\hline \multicolumn{2}{|c|}{ Prior pregnancy } & $86(74.1 \%)$ & $20(27.0 \%)$ & $7(19.4 \%)$ & 0.67 \\
\hline \multicolumn{2}{|c|}{$\begin{array}{l}\text { Gestational diabetes } \\
\text { mellitus }\end{array}$} & $10(8.6 \%)$ & $10(3.5 \%)$ & $8(22.2 \%)$ & 0.09 \\
\hline \multicolumn{2}{|c|}{$\begin{array}{l}\text { Pregnancy induced } \\
\text { hypertension }\end{array}$} & $6(5.2 \%)$ & $6(8.1 \%)$ & $4(6.1 \%)$ & 0.44 \\
\hline \multicolumn{2}{|c|}{ Induced labor } & $43(37 \%)$ & $30(40.5 \%)$ & $20(55.5 \%)$ & 0.14 \\
\hline \multicolumn{2}{|c|}{$\begin{array}{l}\text { Emergency } \\
\text { caesarean delivery }\end{array}$} & $15(12.9 \%)$ & $14(18.9 \%)$ & $13(36.1 \%)$ & $<0.01^{*}$ \\
\hline \multicolumn{2}{|c|}{ Birth weight(mean) } & $3083 g$ & $3170 \mathrm{~g}$ & $3066 \mathrm{~g}$ & 0.29 \\
\hline \multirow[t]{2}{*}{ Apgar score } & $1 \mathrm{~min}$ & 7 & 8 & 7 & 0.08 \\
\hline & $5 \mathrm{~min}$ & 8 & 8 & 8 & 0.26 \\
\hline \multicolumn{2}{|c|}{ Umbilical arterial pH } & 7.27 & 7.26 & 7.29 & 0.39 \\
\hline \multicolumn{6}{|c|}{$\begin{array}{l}\text { - There were } 8164 \text { deliveries in } 5 \text { years, and } 226 \text { parturients who } \\
\text { received epidural labor analgesia were included to the study. } \\
\text { They divided into the } 3 \text { age groups. } \\
\text { - The incidence of pregnancy-induced hypertension and gestational } \\
\text { diabetes mellitus was not different among } 3 \text { age groups. }\end{array}$} \\
\hline
\end{tabular}

\section{Results 2}

Table2 Emergency caesarean delivery rate among 3 age groups

\begin{tabular}{|c|c|c|c|}
\hline & $\begin{array}{c}\text { Delivery with Epidural } \\
\text { labor analgesia }\end{array}$ & $\begin{array}{c}\text { All } \\
\text { delivery }\end{array}$ & p value \\
\hline$<35$ years & $12.9 \%$ & $10 \%$ & 0.29 \\
\hline $35-39$ years & $18.9 \%$ & $13 \%$ & 0.29 \\
\hline $40 \leqq$ years & $36 \%$ & $20 \%$ & $0.01^{*}$ \\
\hline
\end{tabular}

- In each group, emergency caesarean rate was $12.9 \%, 18.9 \%$,

$36.1 \%$ respectively.

- Regarding all the deliveries at our institution, emergency caesarean delivery rate in these 3 age groups was $10 \%, 13 \%$ and $20 \%$ respectively.

Table3 Odds ratio for emergency caesarean delivery by variables

Variables

\begin{tabular}{ll|l} 
OR & $95 \% \mathrm{Cl}$ & $\mathrm{p}$ value
\end{tabular}

Age(vs. $<35$ years)

\begin{tabular}{|l|c|c|c|}
\hline 35-39 years & 1.36 & $0.59-3.15$ & 0.46 \\
\hline $40 \leqq$ years & 3.45 & $1.41-8.45$ & $<0.01^{*}$ \\
\hline Induced labor & 1.52 & $0.74-3.11$ & 0.98 \\
\hline Parity & 2.91 & $0.09-0.871$ & 0.26 \\
\hline Birth weight 4000g over & 1.78 & & 0.03 \\
\hline
\end{tabular}

$\mathrm{Cl}$ : confidence interval OR: odds ratio

- In the multivariate model, aged over 40 is a significant predictor of emergency caesarean delivery.

\section{Discussion}

- Our result demonstrates that there is an increase in the rate of emergency caesarean delivery when epidural labor analgesia is performed on women over 40 compared to women under 35 .

- It has been reported that epidural labor analgesia does not increase the rate of caesarean delivery, and it is widely accepted that it increases the rate of instrumental delivery and prolong the total duration of labor.

- Generally speaking, parturients of advanced age are more likely to suffer from prolonged labor compared to younger women.

Furthermore, epidural analgesia could potentially increase the length of labor for these women.

- Additionally, instrumental delivery has been reported to increase the risk of neonatal complications compared with caesarean delivery.

- According to these reasons, we speculated that caregivers are more prone to offer caesarean delivery to women of advanced age.

\section{Conclusion}

- Epidural labor analgesia for women over 40 is independently associated with the increase risk of caesarean delivery compared to parturient under 35 .

- Although a causal relationship should be examined in a more randomized trial, prenatal care providers should discuss the risks and benefits of epidural analgesia for this age. 